\title{
3 Research Square

\section{In Vitro Regeneration of The Endangered Cactus Turbincarpus Mombergeri Riha, A Hybrid of T. Laui X T. Pseudopectinatus}

Maria del Socorro Santos-Diaz ( $\sim$ ssantos@uaslp.mx )

Faculty of Chemistry University of San Luis Potosí https://orcid.org/0000-0001-5729-196X

Ma. Lourdes Santos-Díaz

Universidad Autónoma de San Luis Potosí: Universidad Autonoma de San Luis Potosi

Juana Alvarado-Rodríguez

Universidad Autónoma de San Luis Potosí: Universidad Autonoma de San Luis Potosi

\section{Research Article}

Keywords: Turbinicarpus mombergeri, micropropagation, endangered cacti, hybrid

Posted Date: July 28th, 2021

DOl: https://doi.org/10.21203/rs.3.rs-742548/v1

License: (c) (i) This work is licensed under a Creative Commons Attribution 4.0 International License.

Read Full License 


\section{Abstract}

Turbinicarpus mombergeri is a cacti species formed by a hybridization process between Turbinicarpus laui and Turbinicarpus pseudopectinatus. Under natural conditions, it is very difficult for two species be genetically compatible for hybridization, and to produce flowers at the same time. Thus, T. mombergeri is a very interesting and a rare species. Unfortunately, the current populations are decreasing and now it is considered critically endangered. The aim of this research was to develop a successful protocol for propagating T. mombergeri using the in vitro culture techniques. Seed disinfection was performed with Plant Preservative Mixture, and $80 \%$ of germination occurred at day 45 in Murashige-Skoog medium. The shoots were cut longitudinally, and the segments were transferred to media containing 2.22 or $4.44 \mu \mathrm{M}$ benzyladenine to induce shooting. The generated shoots were highly hydrated, and presented abundant callus. The hyperhydricity was controlled by reducing salt medium concentration, by increasing calcium levels and by using polyethylenglycol. The reduction of callus was attained by adding tri-iodo benzoic acid. Vigorous and thick shoots were generated in medium containing urea, and rooting improved in the presence of $0.5 \mu \mathrm{M}$ indoleacetic acid. Plantlets with normal morphology were obtained, and the survival rate of the plants in soil was $80 \%$. The methodology developed represents an alternative for propagation of T. mombergeri under controlled conditions for commercial or conservation purposes.

\section{Key Message}

The paper describes several approaches to avoid the hyperhydricity and callus formation, to improve quality of shoots and to increase the development of roots during the micropropagation process of the endangered cacti T. mombergeri.

\section{Introduction}

The Cactaceae family is native to the American continent and comprises about 2,000 species. The major diversity of cacti, however, is located in Mexico, with more than 600 species, of which $80 \%$ are endemic (Ortega-Baes et al. 2010).

Cacti are succulent plants well adapted to dry and desert-like conditions. Many of them possess globeshaped stems, combining the highest possible volume for water storage with the lowest area for water loss by transpiration (Gibson and Nobel 1986). The cacti species are valued in the international market because of the beauty of their flowers and the characteristic morphology of the stems.

Unfortunately, the natural populations of cacti are decreasing because the devastation of their natural habitat and over-collection (Goettsch et al. 2015). According to the Convention on International Trade of Endangered Species (CITES 2015), 35 cacti species are included in Appendix I, among them, several species of the genus Turbinicarpus. Particularly, the native populations of Turbinicarpus mombergeri have suffered the negative effects of plant looting because they are unique and very uncommon in the 
wild (Sotomayor et al. 2004). This species is generated by the hybridization of Turbinicarpus laui (Fig. 1a) and Turbinicarpus pseudopectinatus (Fig. 1b).

Recently, Khan et al. (2020) investigated the genetic architecture of hybridization in four areas of eastern Brazil that contain Melocactus concinnus, M. ernestii, M. glaucescens, M. paucispinus, and M. zehntneri. They observed that the genomic introgression among these species is very low, which confirms that Melocatus maintain their genetic integrity with selection favoring parental genotypes. Thus, the case of $T$, mombergeri generation is rare considering that is difficult that two species be genetically compatible to hybridize and to produce flowers at the same time.

T. mombergeri is a semi-globose cactus and possesses elliptical areoles with most of the spines in the lateral position (Fig. 1c). This species grows in calcareous gypsum rocky soil surrounded by thick xerophilous scrub. A single locality with three areas of occupancy of approximately $10,000 \mathrm{~m}^{2}$ is known. The natural population of T. mombergeri is estimated fewer than 250 adult individuals, therefore, it is considered critically endangered. In addition, the T. mombergeri plants are usually taken from the natural habitat, reaching high prices on the international market (Sotomayor et al. 2004).

An alternative for propagating and preserving rare and threatened cacti are the in vitro culture techniques. By using this methodology, more than one hundred species have propagated, either by organogenesis (Pérez-Molphe et al. 1998; Santos-Díaz et al. 2003a; Lema-Rumińska and Kulus 2014) or by embryogenesis (Moebius-Goldammer et al. 2003; Stuppy and Nagl 1992). In vitro propagation of several species of Turbinicarpus has been previously described (De la Rosa et al. 2012; Dávila-Figueroa et al. 2005), but there is not information about the in vitro culture of T. mombergeri.

The aim of this research was to develop an efficient protocol for regenerating T. mombergeri in vitro and for contributing to its conservation.

\section{Materials And Methods}

\section{Disinfection and germination of seeds}

The seeds of T. mombergeri were donated by the Instituto Nacional de Investigaciones Agrícolas y Pecuarias, in San Luis Potosí. The seeds $(n=20)$ were rinsed with water and commercial soap, maintained in tap water for $1 \mathrm{~h}$ and soaked $72 \mathrm{~h}$ in deionized water. They were immersed in Plant Preservative Mixture $\left(20 \mathrm{ml} \mathrm{L}^{-1}\right)$ for $24 \mathrm{~h}$ with constant agitation at $125 \mathrm{rpm}$. The seeds were germinated in MS medium (Murashige and Skoog 1962) supplemented with $116 \mu \mathrm{M}$ Myo-inositol, $1.2 \mu \mathrm{M}$ thiamine$\mathrm{HCl}, 30 \mathrm{~g} \mathrm{~L}^{-1}$ sucrose and $4 \mathrm{~g} \mathrm{~L}^{-1}$ Phytagel (Sigma-Aldrich, St. Louis, MO, USA). The $\mathrm{pH}$ of the medium was adjusted to 5.7. All cultures were maintained at $25^{\circ} \mathrm{C}$ in a photoperiod of $16 \mathrm{~h}$ light $\left(45 \mu \mathrm{mol} \mathrm{m} \mathrm{m}^{-2} \mathrm{~s}^{-}\right.$ ${ }^{1}$ ) and $8 \mathrm{~h}$ darkness with light supplied by cool-white fluorescent lamps (Phillips, Saltillo, Mexico). The percentage of germination was determined at 7, 14, 30, 45, 60 and 90 days, considering the emergence of radicle as positive germination. 
The seedlings germinated from seeds segmented longitudinally, and the apical tip was removed. The segments were cultivated in MS medium containing $2.22 \mu \mathrm{M}$ (B2) or $4.44 \mu \mathrm{M}$ (B4) benzyladenine (BA) and $1 \%$ activated charcoal (AC), and solidified with $8 \mathrm{~g} \mathrm{~L}^{-1}$ agar (Phyto Technology, KS, USA). The pH medium was adjusted to $\mathrm{pH} 6.7$ to obtain a final of $\mathrm{pH} 5.7$ after sterilization. The percentage of new shoots was evaluated at 30, 60 and 90 days. The presence of callus and hyperhydricity was recorded as: low (less than $10 \%$ of callus or hyperhydricity on the tissue surface), medium (between 10 and $30 \%$ of callus or hyperhydricity on the tissue surface) or high (more than $50 \%$ of callus or hyperhydricity on the tissue surface).

The hydrated shoots of T. mombergeri were cultivated on the following media to reduce hyperhydricity: $1 / 2$ MS (MS medium at $50 \%$ salt concentration); $1 / 4 \mathrm{MS}$ (MS medium at $25 \%$ salt concentration); $1 / 4 \mathrm{MS}-2 \mathrm{Ca}$ ( $1 / 4$ MS with double $\mathrm{Ca}$ concentration); $1 / 4 \mathrm{MS}-2 \mathrm{Ca}-\mathrm{P}$ (1/4 MS medium with double Ca concentration and $1 \%$ polyethyleneglycol); $1 / 2$ WPM-2 $\mathrm{Ca}$ (WPM medium at $50 \%$ salt concentration with double $\mathrm{Ca}$ concentration); $1 / 2$ WPM-2Ca-P (1/2 WPM medium with double Ca concentration and $1 \% \mathrm{PEG})$.

To decrease the callus formation, the shoots were transferred to $1 / 2$ WPM-2Ca-P media with $0.5,1$ or $2 \mathrm{mg}$ $\mathrm{L}^{-1}$ of 2,3,5-triiodobenzoic acid (TIBA, Sigma-Aldrich, St. Louis, MO, USA) final pH of 5.7. The subcultures were performed every 30 days for 90 days.

\section{Rooting of shoots and acclimation}

To promote the root formation, the compact shoots were transferred to $1 \frac{1}{2}$ WPM-2Ca-P (WPC) alone or supplemented with $5.71 \mu \mathrm{M}$ IAA (WPC-1) or $0.5 \mathrm{mg} \mathrm{L}^{-1}$ urea (WPC-2). The percentage of rooting and the length of roots was recorded at 60 and 90 days. Others shoots were maintained in the medium WCPT-2 for 90 days, transferred to medium WCPT- 1 for 60 days and maintained in the WCP medium for 120 days (WCPT-3).

The roots of regenerated plants were washed carefully with tap water to eliminate traces of culture medium, and were treated with Raizone Plus (Fax S.A de C.V, México). The plants were transferred to pots $(6 \times 7 \mathrm{~cm})$ containing a sterilized mixture of commercial soil and sand (1:1) and were covered with plastic bags for 4 weeks to promote a progressive environment acclimation. The bags were gradually perforated to reduce humidity, and after 2 months the plants were uncovered and transferred to greenhouse. The plants survival was recorded after 6 months in ex vitro conditions.

\section{Statistical analysis}

A completely randomized design was selected and significant differences between mean values were evaluated by ANOVA using the Tukey test with a $95 \%$ of significance level with the GraphPad Instat 3 program (GraphPad Software Inc., Version 3.10). 


\section{Results And Discussion}

\section{Shoot induction}

To initiate the in vitro culture of endangered species, the use of seeds is the preferred method because it avoids destroying the mother plants and preserves genetic diversity. In this work, seed disinfection with PPM proved to be efficient, and no contamination was observed (data not shown). This compound is a broad-spectrum biocide with no adverse effects on in vitro seed germination, callus proliferation or callus regeneration.

Although the germination is usually low in seeds with a hard coat (Rojas-Aréchiga and Vazquez-Yanez, 2000), as with T. mombergi, we obtained $80 \%$ of the germination at 45 days (Fig. 2a). Longer periods did not improve the response. The percentage of germination obtained in this study was higher than the data reported for T. laui with in vitro conditions (29\%) or under ex vitro conditions for T. laui (71\%) and T. pseudopectinatus (8\%) (Santos-Díaz et al. 2003b; Flores et al. 2005). In addition, the germination rate was higher than that reported for Turbinicarpus valdezianus and T. subterraneus, which presented $46 \%$ and $90 \%$ of germination at double time (Davila-Figueroa et al. 2005). The best response obtained in this work could be associated with the disinfection protocol. The asepsis of T. laui, T. valdezianus and $T$. subterraneus seeds was performed with sodium hypochlorite and ethanol, which are more aggressive agents than PPM, and therefore could damage the embryo structure. Other factors that affect germination in cacti are age, size, dormancy and origin of seeds (Rojas-Aréchega et al. 1997; RojasAréchiga and Vázquez-Yanes, 2000).

After seed germination, well-defined epicotyls and roots were observed at 30 days, reaching $4 \mathrm{~mm}$ and 5.8 $\mathrm{mm}$, respectively, at 90 days. The presence of spines was evident after 14 days and increased proportionally to time culture (Fig. 2b). Since T. mombergeri is a little known species, there is no information about the germination rate or growth parameters in the wild for comparison.

The epicotyls of T. mombergeri were cut longitudinally, and the segments were transferred to a medium with BA. Because the scarcity of material (14 germinated seeds) only B2 and B4 media were tested. These BA concentrations were selected because, in previous studies, they successfully induced the shoot formation in T. laui (Santos-Díaz et al. 2003b); it also has been reported that BA was efficient in propagating other Turbincarpus species (Pérez-Molphe et al. 2015). Data showed that $50 \%$ and $7 \%$ of the explants cultivated on B2 and B4 media, respectively, regenerated one shoot at 90 days, which were highly hydrated, and presented abundant callus formation (Table 1, Fig. 3a). This response was lower than that reported by Dávila-Figueroa et al. (2005), who obtained between 7.8 to 19.7 shoots per explant during the propagation of several Turbincarpus species. It has described that the heterosis in hybrids can affects the regenerative capacity. For example, the ability for generating in vitro shoots was higher in a tomato parental line than in their hybrids, and this difference was attributed to the heterosis and maternal effects (Ohki et al 1978). Additional genetic studies must be done to determine if this phenomena, is also present in the hybrid T. mombergeri. 
The shoots were transferred to B2 to increase shoot number, and after a second subculture an average of 2.8 shoots per explant were obtained, still hydrated and with abundant callus. Hyperhydricity have been described during micropropagation of many cacti species, such as, Mammillaria gracillis, M. pectinifera, Escobaria minima and Pelecyphora aselliformis, among others (Giusti et al. 2002; Poljuha et al. 2003). This effect has often been considered a physiological response to simultaneous stress factors of the in vitro culture, which negatively impacts the micropropagation efficiency and survival of plants in ex vitro conditions (Debergh et al. 1992). Some biochemical characteristics present in hyperhydric tissues are reduced dry weight, and less lignin, cellulose and calcium content, as well as a low $\mathrm{Ca}^{+2} /$ uronic acid ratio (Kevers et al. 2004).

Hyperhydricity can be reduced by improving ventilation and to decrease ethylene accumulation in vessels; by adding osmotic agents (mannitol, polyethylenglycol), to diminish the water potential of media and to low the water content in tissues; by decreasing the concentration of nutrients in the medium; or by increasing the Ca concentration (Thomas et al. 2002; Snyman et al. 2011; Nikam et al. 2019).

Therefore, to reduce the hyperhydricity in T. mombergeri shoots, the effect of culture media (MS, $1 / 2 \mathrm{MS}, 1 / 4$ MS, $1 / 2$ WPM media), osmotic agents ( $1 \% \mathrm{PEG}$ ) and double calcium concentration (2Ca) were tested. The reduction in salts concentration in $1 / 2$ MS medium generated $21 \%$ of compact shoots at 90 days. This percentage improved in $1 / 4$ MS medium or $1 / 2$ WPM medium containing $2 \mathrm{Ca}$ concentration and PEG, generating between 80 to $90 \%$ of compact shoots or shoots with a very low degree of hyperhydricity (Table 2).

The beneficial calcium effects could be attributed to the cell walls strengthening, providing rigidity by reversibly cross-linking with the pectic chains. Its association with plasma membrane also helps to maintain its stability by bridging phosphate and carboxylate groups (White and Broadley 2003). Calcium was also important for vegetative buds formation, and the development of flowers and roots in tobacco pith explants (Capitani and Altamura 2004). Furthermore, it is an essential element for cactus nutrition, representing $85 \%$ of dry weight in some species (Gallaher 1975). As T. mombergeri grows in calcareous soil, high levels of Ca might be required for good shoot development.

Reduction on salt concentration also seem to influence the T. mombergeri shoots compaction since the use of $1 / 2$ MS, $1 / 4$ MS or $1 / 2$ WPM media generated a higher number of compact shoots than the use of MS medium. Better results were obtained in $1 / 2$ WPM medium compared to $1 / 2$ MS medium. The major differences in macronutrients among these media are in ammonium and nitrate ion concentrations, as well as, total ion concentration. Full-strength MS is high in ammonium $(20.6 \mathrm{mM})$ and nitrate ions (39.4 $\mathrm{mM})$, while WPM contains lower concentrations of both ammonium $(5 \mathrm{mM})$ and nitrate $(9.7 \mathrm{mM})$ ions. It has been reported that the ratio of $\mathrm{NH}_{4}: \mathrm{NO}_{3}$ affects the levels of hyperhydricity in several species, such as, Aloe polyphylla (Ivannova and Van Staden 2008) and date palm (El-Dawayati and Zayed 2017). Thus, a reduction in the $\mathrm{NH}_{4}: \mathrm{NO}_{3}$ ratio could also contribute to reducing the hyperhydricity of $T$. mombergeri shoots. 
On the other hand, $100 \%$ of shooting was observed in $1 \frac{1}{2}$ WPM-2Ca-P medium (Table 2 ) generating two shoots per explant. Although the formation of compact shoots was attained, the presence of callus was still very high as shown in Fig. 3b.

Several approaches have been used to reduce callus formation, including cytokinin elimination or the employment of auxin transport inhibitors, such as TIBA. This compound enhanced somatic embryogenesis in groundnut and shoot formation in Morus alba (Venkatesh et al. 2009; Bhau and Wakhlu 2001) and enhanced Rosa hybrida micropropagation (Singh and Syamal 2000). Thus, we cultivated the T. mombergeri shoots in $1 / 2$ WPM-2Ca-P added with $0.5,1$ and $2 \mathrm{mg} \mathrm{L}^{-1}$ TIBA. The callogenesis was reduced in the presence of TIBA proportionally to the concentration (Table 3). This result suggests that the T. mombergi shoots must synthesize high levels of endogenous auxins that are responsible for callus generation. Figure $3 c$ shows the aspect of $T$. mombergeri shoots without callus at 90 days of culture.

\section{Root formation and transfer to soil}

The compact shoots ( 2 to $3 \mathrm{~cm}$ high) were transferred to media $1 / 2$ WPM-2Ca-P medium with $1 \mathrm{mg} \mathrm{L}^{-1}$ TIBA (named WCPT) alone or in combination with $5.7 \mu \mathrm{M} \mathrm{IAA} \mathrm{(WCPT-1)} \mathrm{or} 0.5 \mathrm{mg} \mathrm{L}^{-1}$ urea (WCPT-2) to induce the rooting of shoots (Table 4). After 90 days in the WCPT medium, $21.7 \%$ of the explants developed roots of approximately $3.8 \mathrm{~mm}$ long. In WCPT-1 medium, the percentage of rooting lightly increased and longer roots $(4.6 \mathrm{~mm})$ were generated at 90 days. A reduction on compact shoots, however, was observed according to time, probably because of the presence of the auxin in the medium, which induced an incipient callus formation.

The shoots cultivated in media WCPT-2 generated the lowest percentage of rooting, the root length was similar to that obtained in the WCPT-1 medium, but the shoots duplicated their diameter at 90 days (Fig. 3d).

Taking in account these results, an additional experiment was performed (WCP-3). The shoots were maintained in the medium WCPT-2 for 90 days to generate wide and thick shoots. The plant material was then transferred to medium WCPT- 1 for 60 days, to induce a vigorous radical system, and was finally maintained in the WCP medium for 120 days (Table 4). Using this strategy, the callus formation was avoided completely, and at the end of experiment $96 \%$ of rooted shoots were generated with well-defined roots from with an average length of $13 \mathrm{~mm}$. Figure $3 \mathrm{e}$ shows the aspect of rooted shoots after 1 year in culture. These results shows that T. mombergeri requires a long period to develop strong roots. In wild conditions, most Turbinicarpus species exhibit a very thick primary root, which represents $80 \%$ of the plant body, and acts like an anchor, and more importantly, as water storage for dry periods. The root growth is therefore a time- consuming event.

The beneficial effect of urea in growth and rooting of T. mombergeri shoots is attributed to a higher availability and better absorption of organic nitrogen. It is well known that nitrogen is required for the synthesis of chlorophyll and for amino acid metabolism, which are essentials for plant growth and 
development. Several urea transporters have been identified across different cellular membranes. For example, in Arabidopsis, a symporter, that cotransports urea with protons at high affinity, has been described. In the tonoplast, various tonoplast intrinsic proteins (TIPs), a subfamily of aquaporins, transport urea in a channel-like manner. These transporters seem to optimize the nitrogen intake and compartmentation in dependence of the nitrogen forms being available in the medium (Kojima et al. 2006). Further studies must be done to identify the putative urea transporters in Turbinicarpus species.

The T. mombergeri plants were transferred to soil, and $85 \%$ survived after 1 year. At this period, the plants showed the characteristic spines pattern observed in mature plants (Fig. 3f).

In summary, this work shows that reduction of salt medium concentration, high level of calcium concentration and presence of PEG reduced the shoots hyperhydricity. The addition of TIBA decreased caulogenesis and the presence of urea promoted the development of thick shoots. The protocol developed allowed the successful micropropagation of the critically endangered cacti T. mombergeri, contributing to its conservation.

\section{Declarations}

\section{Funding}

The authors thank to SEMARNAT-CONACYT for the financial support (Project 2002-C01-500).

\section{Conflicts of interest/Competing interests}

The authors declare that there is no conflict of interest.

\section{Availability of data and material (data transparency)}

Data and material are available at the Faculty of Chemistry, UASLP.

\section{Code availability (software application or custom code)}

The software used was Microsoft Word.

\section{Ethics approval}

No animals or persons were used in this work.

\section{Consent to participate}

MLSD, JRA and MSSD give their consent to participate in this paper.

\section{Consent for publication}

MLSD, JRA and MSSD give their consent for the publication of this paper. 
Acknowledgements

We are grateful to CONACYT for the scholarship to JAR, and to the Biologist Alberto Arredondo Gómez for the kind donation of T. mombergeri seeds.

\section{Authors contributions:}

MLSD realized the propagation of shoots, the experiments focused on reduction of hyperhydricity and callus formation, and the rooting of shoots.

JAR participated in the germination of seeds and induction of T. mombergeri shoots.

MSSD is the leader of the group, designed the project and experimental work, participated in revision, discussion of results, wrote the paper and elaborated tables and figures.

\section{References}

1. Bhau BS, Wakhlu AK (2001) Effect of genotype, explant type and growth regulators on organogenesis in Morus alba. Plant Cell Tiss Org Cult 66::25-29. https://doi.org/10.1023/A:1010617212237

2. Capitani F, Altamura MM (2004) Exogenous calcium enhances the formation of vegetative buds, flowers and roots in tobacco pith explants cultured in the absence of exogenous hormones. Plant Cell Tiss Org Cult 77:1-10. https://doi.org/10.1023/B:TICU.0000016608.08095.0f

3. Convention on International Trade in Endangered Species (CITES) (2015) Appendix I and II. U.S. Fish and Wildlife Service, Washington, DC, USA

4. Dávila-Figueroa CA, De la Rosa-Carrillo ML, Pérez-Molphe-Balch E (2005) In vitro propagation of eight species or subspecies of Turbinicarpus (Cactaceae). In Vitro Cell Develop Biol Plant 41:540-545. https://doi.org/10.1079/IVP2005668

5. Debergh P, Aitken-Christie J, Cohen D, Grout B, Von Arnold S, Zimmerman R, Ziv M (1992) Reconsideration of the term vitrification as used in micropropagation. Plant Cell Tiss Org Cult 30:140-165. https://doi.org/10.1007/BF00034307

6. El-Dawayati MM, Zayed ZE (2017) Controlling hyperhydricity in date palm in vitro culture by reduced concentration of nitrate nutrients. In: Al-Khayri J, Jain S, Johnson D (eds) Date Palm Biotechnology Protocols Volume I. Methods in Molecular Biology, vol 1637. Humana Press, New York. https://doi.org/10.1007/978-1-4939-7156-5_15

7. Flores J, Arredondo A, Jurado E (2005) Comparative seed germination in species of Turbinicarpus: an endangered cacti genus. Nat Areas J 25:83-187

8. Gallaher RN (1975) The occurrence of calcium in plant tissue as crystals of calcium oxalate. Commun Soil Sci Plant Anal 6:315-321. https://doi.org/10.1080/00103627509366570 
9. Gibson Ac, Nobel PS (1986) The cactus primer. Cambridge, MA and London, England: Harvard University Press, 2013. https://doi.org/10.4159/harvard.9780674281714

10. Giusti P, Vitti D, Fiocchetti F, Colla G, Saccardo F, Tucci M (2002) In vitro propagation of three endangered cactus species. Sci Hort 95:319-332. https://doi.org/10.1016/S0304-4238(02)00031-6

11. Goettsch B, Hilton-Taylor C, Cruz-Piñón G et al (2015) High proportion of cactus species threatened with extinction. Nat Plants 1:15142. https://doi.org/10.1038/nplants.2015.142

12. Ivanova M, Van Staden J (2011) Influence of gelling agent and cytokinins on the control of hyperhydricity in Aloe polyphylla. Plant Cell Tiss Org Cult 104:13-21. https://doi.org/10.1007/s11240-010-9794-5

13. Khan G, Franco FF, Silva GAR, Bombonato JR, Machado M, Alonso DP, Ribolla PEM, Albach DC, Moraes EM (2020) Maintaining genetic integrity with high promiscuity: Frequent hybridization with low introgression in multiple hybrid zones of Melocactus (Cactaceae). Mol Phylogenet Evol 142:106642. https://doi.org/10.1016/j.ympev.2019.106642

14. Kojima S, Bohner A, von Wirén N (2006) Molecular mechanisms of urea transport in plants. J Membrane Biol 212:83-91. https://doi.org/10.1007/s00232-006-0868-6

15. Kevers C, Franck T, Srasser RJ, Dommes J, Gaspar T (2004) Hyperhydricity of micropropagated shoots: a typically stress-induced change of physiological state. Plant Cell Tiss Org Cult 77:181191. https://doi.org/10.1023/B:TICU.0000016825.18930.e4

16. Lema-Rumińska J, Kulus D (2014) Micropropagation of cacti-a Review. Haseltonia 19:46-63. https://doi.org/10.2985/026.019.0107

17. Moebius-Goldammer KG, Mata-Rosas M, Chávez-Avila VM (2003) Organogenesis and somatic embryogenesis in Ariocarpus kotschoubeyanus (Lem.) K. Schum. (Cactaceae), an endemic and endangered Mexican species. In Vitro Cell Develop Biol Plant 39: 388-393. https://doi.org/10.1079/IVP2003427

18. Murashige T, Skoog F (1962) A revised medium for rapid growth and bio assays with tobacco tissue cultures. Physiol Plant 15:473-497. https://doi.org/10.1111/j.1399-3054.1962.tb08052.x

19. Nikam TD, Mulye KV, Chambhare MR, Nikule HA, Ahire ML (2019) Reduction in hyperhydricity and improvement in in vitro propagation of commercial hard fibre and medicinal glycoside yielding Agave sisalana Perr. ex Engelm by $\mathrm{NaCl}$ and polyethylene glycol. Plant Cell Tiss Org Cult 138:67-78. https://doi.org/10.1007/s11240-019-01603-9

20. Ortega-Baes P, Sühring S, Sajama J, Sotola E, Alonso-Pedano M, Bravo S, Godínez-Álvarez H (2010) Diversity and conservation in the cactus family. In: Ramawat KC (ed) Desert Plants. Springer, Berlin, pp 157-173

21. Pérez Molphe-BachE, Pérez-Reyes ME, Villalobos-Amador E, Meza-Rangel E, Morones-Ruiz LR, Lizalde-Viramontes JH (1998) Micropropagation of 21 species of Mexican cacti by axillary proliferation. In Vitro Cell Dev Biol Plant 34:131-135. https://doi.org/10.1007/BF02822777

22. Poljuha D, Balen B, Bauer A, Ljubesic N, Krsnik M (2003) Morphology and ultrastructure of Mammillaria gracillis (Cactaceae) in in vitro culture. Plant Cell Tiss Org Cult 75:117-123. 
https://doi.org/10.1023/A:1025030115905

23. Rojas-Aréchiga M, Vázquez-Yanes C (2000) Cactus seed germination: a review. J Arid Environ 44:85104. https://doi.org/10.1006/jare.1999.0582

24. Rojas-Aréchiga M, Orozco-Segovia A, Vázquez-Yanes C (1997) Effect of light on germination of seven species of cacti from the Zapotitlán Valley in Puebla, Mexico. J Arid Environ 36:571-578. https://doi.org/10.1006/jare.1996.0218

25. De la Rosa-Carrillo ML, Domínguez-Rosales MS, Pérez-Reyes ME, Pérez Molphe-Balch E (2012) In vitro culture and propagation of threatened cacti of the Turbinicarpus genus. Interciencia 37: 114120

26. Santos-Díaz MS, Méndez-Ontiveros R, Arredondo-Gómez A, Santos-Díaz ML (2003a) In vitro organogenesis of Pelecyphora aselliformis Erhenberg (cactaceae). In Vitro Cell Dev Biol Plant 39:480-484. https://doi.org/10.1079/IVP2003456 Santos Díaz 2003 b

27. Santos-Díaz MS, Méndez-Ontiveros R, Arredondo-Gómez A, Santos-Díaz ML (2003b) Clonal propagation of Turbinicarpus laui Glass \& Foster, a cactus threatened with extinction. Bradleya 21:712. https://doi.org/10.25223/brad.n21.2003.a3

28. Singh S, Syamal M (2000) Anti-auxin enhance Rosa Hybrida L. micropropagation. Biol Plant 43:279281. https://doi.org/10.1023/A:1002768613872

29. Sotomayor-Martín del Campo M, Arredondo Gómez A, Sánchez Barra FR, Martínez Méndez M (2004) The genus Turbinicarpus in San Luis Potosí. Cactus \&Co, Venegono, pp 82-87

30. Stuppy W, Nagl W (1992) Regeneration and propagation of Ariocarpus retusus Scheidw. (Cactaceae) via somatic embryogenesis. Bradleya 10:85-88. https://doi.org/10.25223/brad.n10.1992.a7

31. Thomas P, Mythili JB, Stumman BM, Shivashankar KS (2000) Explant, medium and vessel aeration affect the incidence of hyperhydricity and recovery of normal plantlets in triploid watermelon. J Hort Sci Biotech 75:19-25. doi 10.1080/14620316.2000.11511194

32. Snyman SJ, Nkwanyana PD, Watt MP (2011) Alleviation of hyperhydricity of sugarcane plantlets produced in RITA $\circledast$ vessels and genotypic and phenotypic characterization of acclimated plants. South Afr J Bot 77:685-692. https://doi.org/10.1016/j.sajb.2011.03.004

33. Venkatesh K, Roja Rani A, Baburao N, Padmaja G (2009) Effect of auxins and auxin polar transport inhibitor (TIBA) on somatic embryogenesis in groundnut (Arachis hypogaea L.). Afr J Plant Sci 3:288-293. https://doi.org/10.5897/AJPS.9000073

34. White PJ, Broadly MR (2003) Calcium in plants. Ann Bot 92:487-511. https://doi.org/10.1093/aob/mcg164

\section{Tables}


Table 1

Induction of Turbinicarpus mombergeri shoots in medium with benzyladenine at 90 days

\begin{tabular}{|lllllllllll|}
\hline Medium $^{1}$ & $\begin{array}{l}\text { Shooting }^{2} \\
\text { (\%) }\end{array}$ & \multicolumn{2}{l}{$\begin{array}{l}\text { Hyperhydricity } \\
\text { (\%) }\end{array}$} & & \multicolumn{5}{l|}{$\begin{array}{l}\text { Callus } \\
\text { (\%) }\end{array}$} \\
\hline & & 0 & Low & Medium & High & 0 & Low & Medium & High \\
\hline MS-B2 & $50 \mathrm{a}$ & 0 & 28 & 28 & 44 & 14 & 28 & 44 & 14 \\
\hline MS-B4 & $7 \mathrm{~b}$ & 0 & 0 & 0 & 100 & 0 & 100 & 0 & 0 \\
\hline
\end{tabular}

${ }^{1}$ MS-B2: medium MS with $2.22 \mu \mathrm{M}$ BA; MS-4: MS with $4.44 \mu \mathrm{M}$ BA

${ }^{2}$ Means with different letter differed significantly (Tukey test, $p \leq 0.05$ ).

${ }^{3}$ Low: less than $10 \%$ of callus or hyperhydricity on the tissue surface; medium (10-30\% of callus or hyperhydricity on the tissue surface; high $>50 \%$ of callus or hyperhydricity on the tissue surface.

Table 2

Effect of medium components in hyperhydricity of Turbinicarpus mombergeri shoots at 90 days

\begin{tabular}{|c|c|c|c|c|c|c|c|}
\hline \multirow[t]{2}{*}{ Medium $^{a}$} & \multirow[t]{2}{*}{$\mathrm{n}$} & \multirow{2}{*}{$\begin{array}{l}\text { Shoots per } \\
\text { Explant }\end{array}$} & \multirow[t]{2}{*}{ Shooting (\%) } & \multicolumn{4}{|c|}{ Hyperhydricity (\%) } \\
\hline & & & & 0 & Low & Medium & High \\
\hline MS & 28 & $0.25 \mathrm{~d}$ & 25 & 0 & 14 & 43 & 43 \\
\hline $1 / 2 \mathrm{MS}$ & 28 & $1.39 \mathrm{~b}$ & 86 & 21 & 33 & 23 & 23 \\
\hline $1 / 4 \mathrm{MS}-2 \mathrm{Ca}-\mathrm{P}$ & 41 & $0.39 d$ & 39 & 34 & 56 & 9 & 0 \\
\hline $1 / 2$ WPM-2Ca & 24 & $0.79 \mathrm{c}$ & 79 & 41 & 54 & 4.1 & 0 \\
\hline 1/2 WPM-2Ca-P & 33 & $2.12 \mathrm{a}$ & 100 & 33 & 63 & 3 & 0 \\
\hline
\end{tabular}

$1 / 2$ MS: MS medium at $50 \%$ salt concentration; $1 \frac{1}{4}$ MS: MS medium at $25 \%$ salt concentration; $1 / 4$ MS-2Ca-P: $1 / 4$ MS medium with double Ca concentration and 1\% PEG; $1 / 2$ WPM- 2 Ca: WPM medium at $50 \%$ salt concentration with double Ca; 122 WPM-2Ca-P: $1 / 2$ WPM medium with double $\mathrm{Ca}$ and $1 \%$ PEG. All media contained $1 \%$ activated charcoal. Values with different letter are statistically different (Tukey test, $\mathrm{p}<0.05)$ 
Table 3

Effect of TIBA on callus formation of Turbinicarpus. mombergeri shoots at 90 days $^{a}$

\begin{tabular}{|c|c|c|c|c|c|c|}
\hline \multirow{2}{*}{$\begin{array}{l}\text { TIBA } \\
\text { concentration } \\
\left(\mathrm{mg} \mathrm{L}^{-1}\right)\end{array}$} & \multirow[t]{2}{*}{$\mathbf{n}$} & \multirow{2}{*}{$\begin{array}{l}\text { Shoots per } \\
\text { Explant }\end{array}$} & \multicolumn{4}{|c|}{ Callus formation (\%) } \\
\hline & & & 0 & Low & Medium & High \\
\hline 0.5 & 36 & $1.36 b$ & 38.8 & 61.2 & 0 & 0 \\
\hline 1 & 46 & $1.65 b$ & 41.3 & 58.7 & 0 & 0 \\
\hline 2 & 50 & $1.88 \mathrm{~b}$ & 82 & 18 & 0 & 0 \\
\hline
\end{tabular}

a The medium used was $1 / 2$ WPM with double Ca concentration and $1 \%$ PEG, pH 5.7. Values with different letter are statistically different (Tukey test, $p<0.05$ )

Table 4

Rooting of Turbinicarpus mombergeri shoots

\begin{tabular}{|lllll|}
\hline Treatment $^{1}$ & Time (days) & $\begin{array}{l}\text { Compact } \\
\text { shoots }(\%)\end{array}$ & $\begin{array}{l}\text { Rooting } \\
(\%)\end{array}$ & $\begin{array}{l}\text { Root length } \\
(\mathrm{mm})\end{array}$ \\
\hline WCPT (Control) & 30 & 75 & 0 & - \\
\cline { 2 - 4 } & 60 & 91 & 0 & - \\
\hline WCPT-1 & 90 & 100 & 21.7 & $3.8 \pm 0.08$ \\
& 30 & 82 & 0 & - \\
\hline WCPT-2 & 60 & 73 & 26 & $3.8 \pm 0.07$ \\
& 90 & 69 & 26 & $4.6 \pm 0.06$ \\
& 30 & 52 & 0 & - \\
\hline WCPT-3 & 90 & 73 & 17 & $3.5 \pm 0.05$ \\
& 90 (WCPT-1) & 92 & 60 & $8.75 \pm 0.3$ \\
& 60 (WCPT-2) & 96 & 70 & $10 \pm 0.4$ \\
\hline & 120 (Control) & 96 & 96 & $13 \pm 0.7$ \\
\hline
\end{tabular}

${ }^{1}$ WCPT: $1 / 2$ WPM medium with double Ca concentration, $1 \%$ PEG, $1 \mathrm{mg} \mathrm{L}^{-1}$ TIBA; WCPT1: WCPT medium with $5.71 \mu \mathrm{M}$ IAA; WCPT-2: WCP medium with $0.5 \mathrm{mg} \mathrm{L}^{-1}$ urea;WCPT-3: shoots were maintained in WCPT-2 medium for 90 days, transferred to WCPT- 1 for 60 days and to WCPT medium for 120 days. 


\section{Supplemental Data}

Appendix files are not available with this version.

\section{Figures}

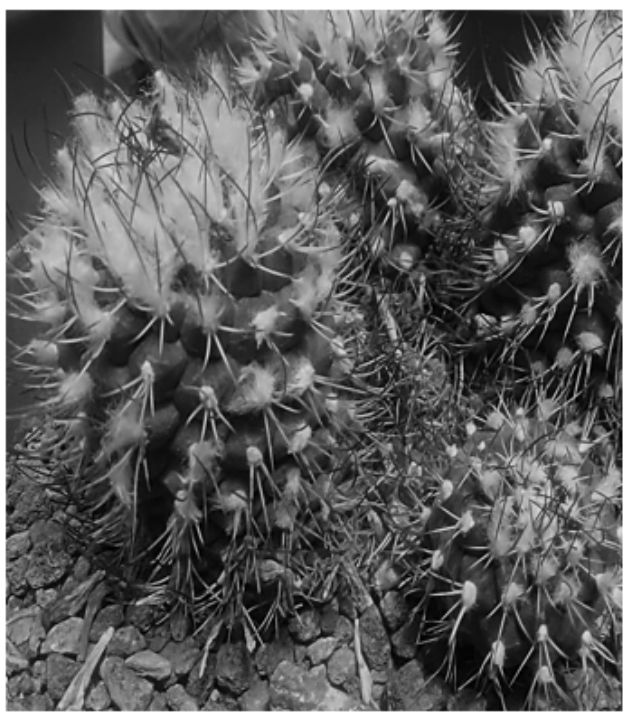

(a)

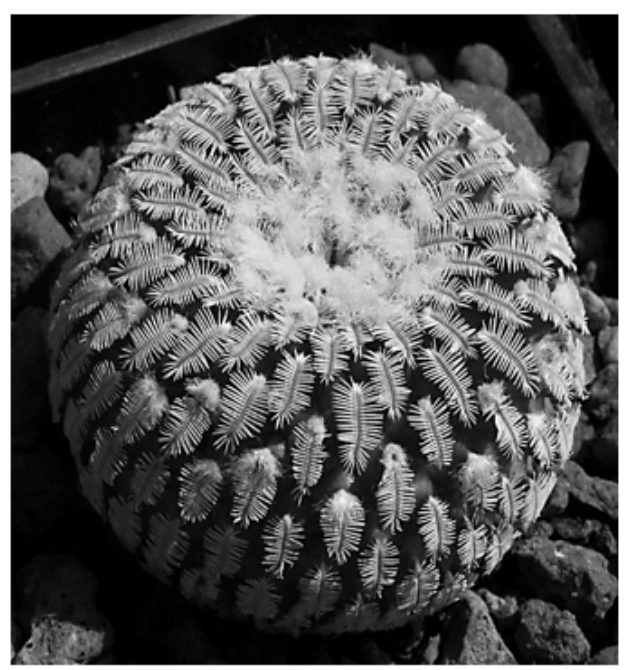

(b)

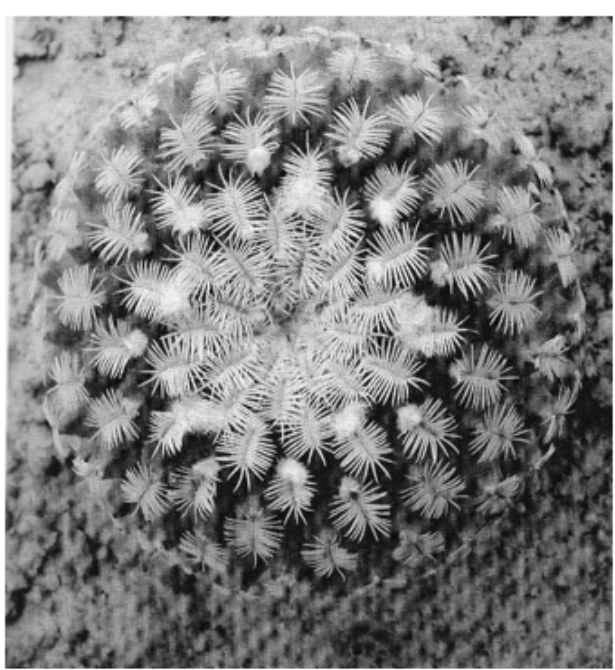

(c)

\section{Figure 1}

Aspect of mature plants of a) Turbinicarpus laui, b) Turbinicarpus pseudopectinatus, and c) the hybrid Turbinicarpus mombergeri

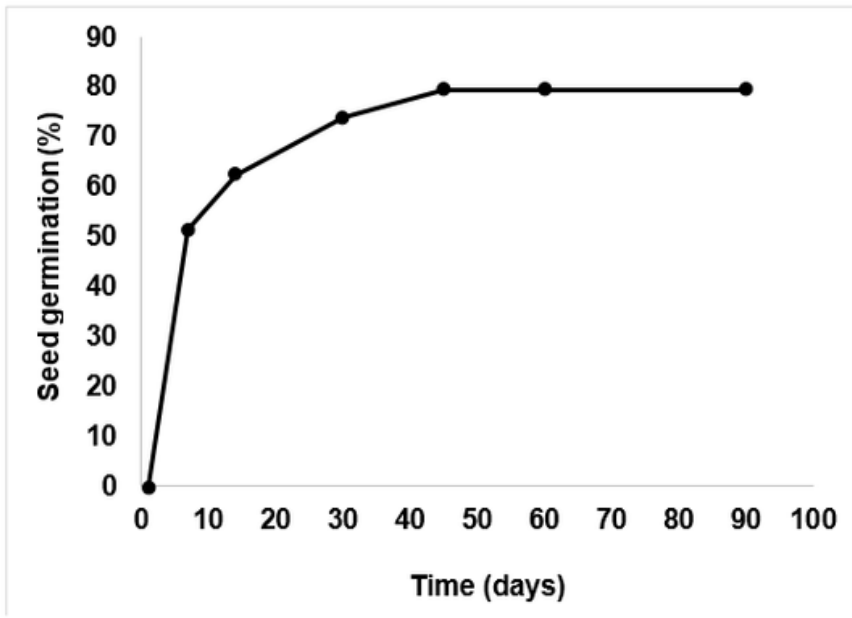

a

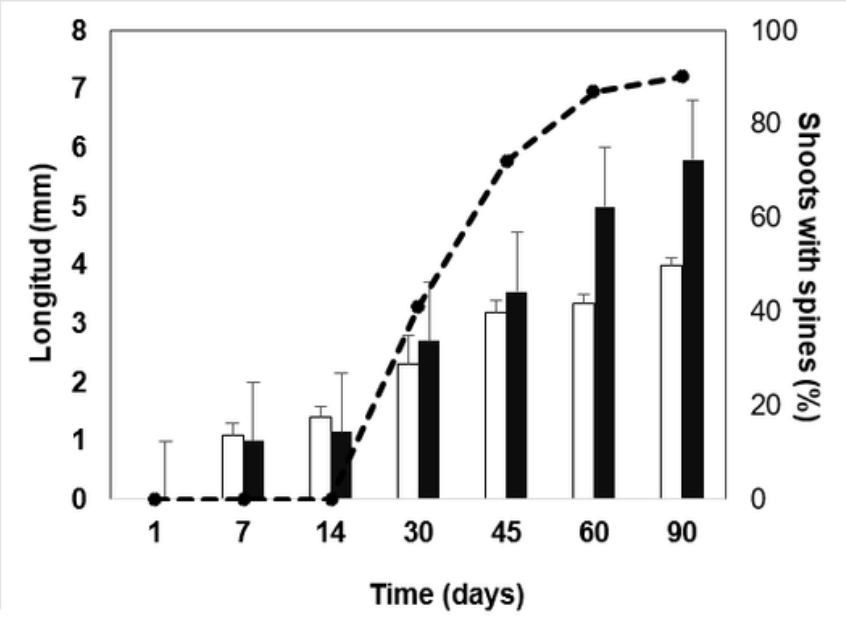

Figure 2

Germination and development of seedlings of Turbincarpus mombergeri. a) Percentage of germination and $b$ ) increase in epicotyl length (white columns), root length (black columns) and percentage of shoots with spines (dotted line). Bars represent \pm SD. 

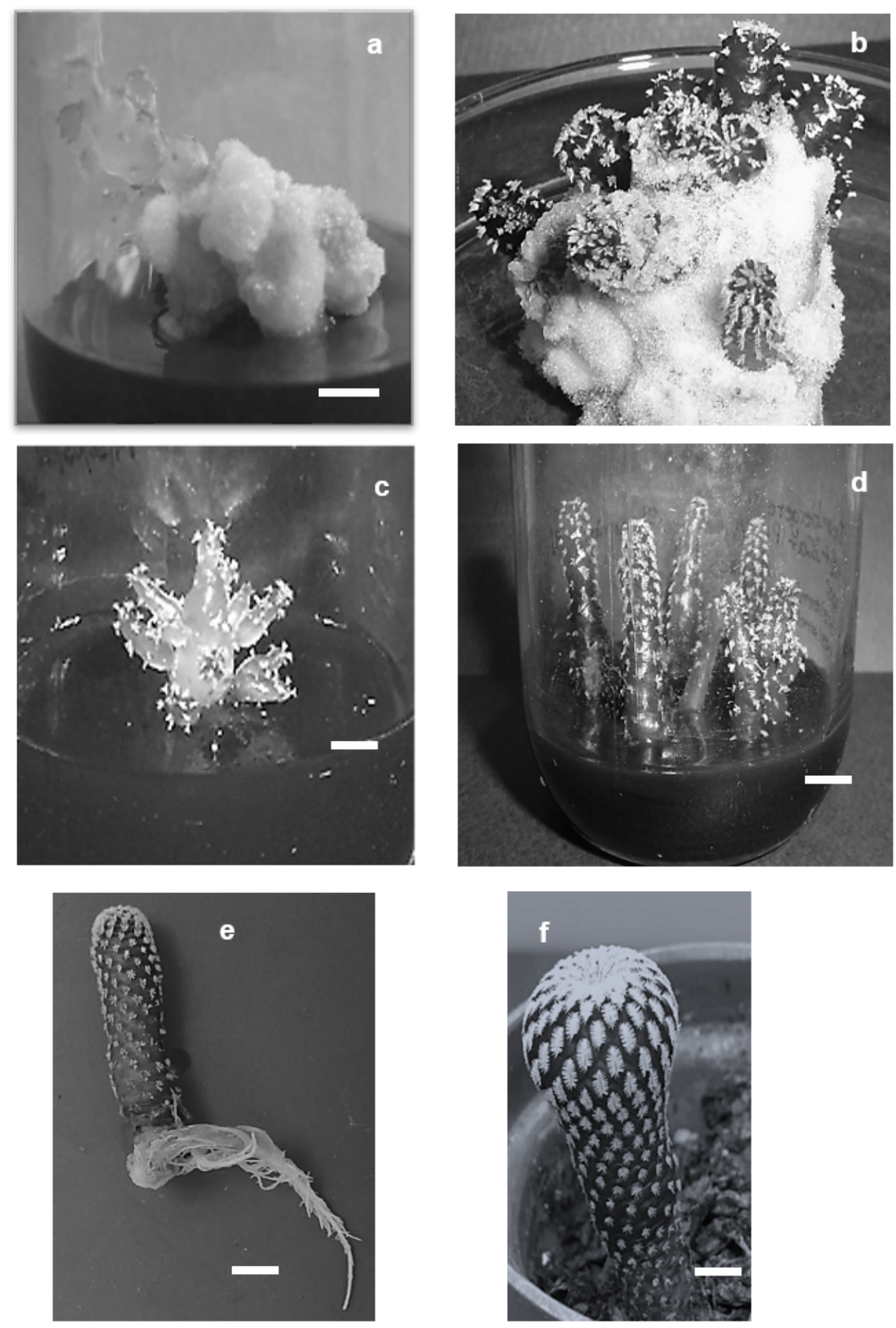

\section{Figure 3}

Different stages of Turbinicarpus mombergeri in vitro propagation. a) hyperhydric shoots induced in medium B2, b) compact shoots generated in $1 / 2$ WPM-2Ca-P medium at 90 days, c) shoots without callus cultivated in medium with $2 \mathrm{mg} \mathrm{L-1}$ TIBA, d) thick shoots formed in medium with $0.5 \mathrm{mg}$ L-1 urea, e) rooted shoots after 1 year in culture, f) well-defined pattern of spines in adapted plants to soil. 